International Journal of Life Sciences
Available online at www.sciencescholar.us
Vol. 4 No. 1, April 2020, pages: $26-36$
e-ISSN: 2550-6986, p-ISSN: 2550-6994
https://doi.org/10.29332/ijls.v4n1.387

\title{
Agribusiness Development Model for Strengthening the Chili- Tobacco Intercropping Farmer Group
}

\author{
(1) CrossMark \\ I Nengah Surata Adnyana a, Dwi Putra Darmawan b, I Wayan Windia c, I Ketut Suamba d \\ Manuscript submitted: 09 November 2019 Manuscript revised: 18 December 2019, Accepted for publication: 27 January 2020
}

Corresponding Author ${ }^{\text {a }}$

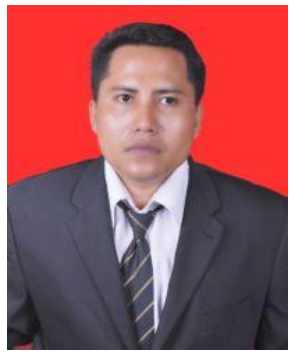

Keywords

agribusiness system;

chili-tobacco;

farmer groups;

field school;

intercropping;

\begin{abstract}
The objectives of this study are (1) to analyze the influence of the procurement and distribution subsystems of production facilities for strengthening the ChiliTobacco Inter-cropping Farmer Group in Bali Province; (2) analyzing the influence of farming subsystems for strengthening the Chili-Tobacco Intercropping Farmer Group in Bali Province; (3) analyzing the effect of post-harvest handling and further processing subsystems for strengthening the ChiliTobacco Inter-cropping Farmer Group in Bali Province; (4) analyze the effect of the yield marketing subsystem to strengthen the Chili-Tobacco Inter-cropping Farmer Group in Bali Province; (5) analyzing the effect of supporting services subsystems for strengthening the Chili-Tobacco Inter-cropping Farmer Group in Bali Province; and (6) designing an agribusiness system development model that is suitable for strengthening the Chili-Tobacco Inter-cropping Farmer Group in the Province of Bali. The methodology uses Smart PLS analysis and the SAST (Strategic Assumption Surfacing and Testing) method in determining the implementation of activity level needs for farmer groups.
\end{abstract}

International Journal of Life Sciences (C) 2020.

This is an open access article under the CC BY-NC-ND license (https://creativecommons.org/licenses/by-nc-nd/4.0/).

\section{Contents}

Abstract

1 Introduction.

3 Results and Discussions

3.1 The influence of the procurement and distribution subsystems of production facilities for strengthening the chili-tobacco intercropping farmer groups

3.2 The influence of farming subsystems for strengthening the chili-tobacco intercropping farmer

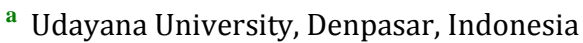

b Udayana University, Denpasar, Indonesia

c Udayana University, Denpasar, Indonesia

d Udayana University, Denpasar, Indonesia 
Groups

3.3 The effects of post-harvest subsystems and further processing for strengthening of chilli-tobacco intercropping farmer groups.

3.4 The effect of yield marketing subsystems on strengthening the chili-tobacco intercropping farmer groups

3.5 The effect of the supporting services subsystem for strengthening the chili-tobacco intercropping farmer groups

3.6 Development Model of the Agribusiness System that is suitable for Strengthening the Chili-Tobacco intercropping Farmer Group.

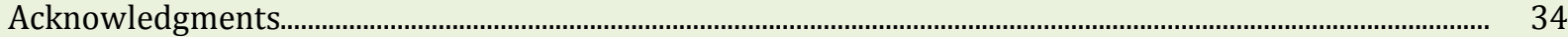

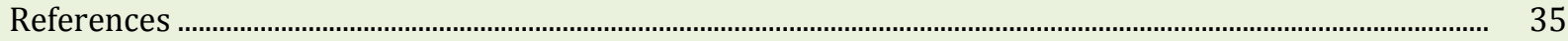

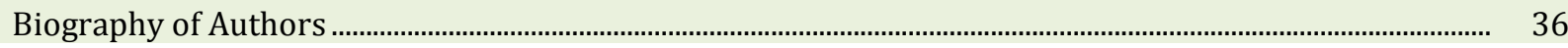

\section{Introduction}

The development of a country that does not pay attention to the agricultural sector will bring unfavorable impacts on economic development. For example, there will be a lot of poverty, unemployment, difficulty achieving food security and sovereignty, and economic inequality, as experienced by Indonesia, which is an agrarian country, where most of the population's livelihoods are farming.

Overcoming these problems can be done in several ways, namely: (1) the approach taken must be able to solve economic problems; (2) the approach chosen must be able to utilize the results of previous development so that the development that has been carried out can be of good use; and (3) the approach made must be able to bring the Indonesian economy to become stronger, more advanced and more synergistic (interdependency economy) with the international world economy (Saragih, 2003). Among the existing economic approach strategies, the development approach that meets these characteristics is developed with the concept of agribusiness.

One of Indonesia's agricultural commodities that has local potentials based on populist development is the chili-tobacco intercropping commodity. The chili-tobacco commodity is one of the leading commodities of the Ministry of Agriculture program. The development of the harvested area of various chili and smallholder tobacco plants in Indonesia nationally in the period 2013 to 2016 continues to experience fluctuations in both harvested area, production and productivity as shown in Table 1.

Table 1

Harvested area, production, and productivity of various Indonesian chili and tobacco commodities nationally from 2013 to 2016

\begin{tabular}{llllllll}
\hline & & \multicolumn{6}{c}{ Commodity } \\
\cline { 3 - 8 } No & Year & \multicolumn{3}{c}{ Various kinds of chili } & \multicolumn{3}{c}{ Smallholder tobacco plants } \\
\cline { 3 - 8 } & & $\begin{array}{l}\text { Harvested } \\
\text { Area (Ha) }\end{array}$ & $\begin{array}{l}\text { Production } \\
\text { (Ton) }\end{array}$ & $\begin{array}{l}\text { Productivity } \\
\text { (Ton/Ha) }\end{array}$ & $\begin{array}{l}\text { Harvested } \\
\text { Area (Ha) }\end{array}$ & $\begin{array}{l}\text { Production } \\
\text { (Ton) }\end{array}$ & $\begin{array}{l}\text { Productivity } \\
\text { (Ton/Ha) }\end{array}$ \\
\hline 1 & 2013 & 249.232 & 1.726 .381 & 6.92 & 189.700 & 161.300 & 0,85 \\
2 & 2014 & 263.616 & 1.875 .095 & 7.11 & 206.900 & 196.100 & 0.94 \\
3 & 2015 & 255.716 & 1.915 .154 & 7.48 & 208.300 & 192.900 & 0.92 \\
4 & 2016 & 260.222 & 1.961 .598 & 7.53 & 205.500 & 195.600 & 0.95 \\
\hline \multicolumn{2}{l}{ Average } & 257.196 & 1.869 .557 & 7,26 & 202.600 & 186.475 & 0,91 \\
\hline
\end{tabular}

Source: Central Bureau of Statistics, 2017

Bali Province which has an area of $5,636.66 \mathrm{~km}^{2}$ or $0.29 \%$ of the land area of Indonesia; with an area of 353,491 ha of agricultural land consisting of 79,526 ha of paddy land and 273,965 ha of non-paddy land and 210,175 ha of non-agricultural land (Bali Provincial Statistics Office, 2017). Based on the area of paddy fields

Adnyana, I. N. S., Darmawan, D. P., Windia, I. W., \& Suamba, I. K. (2020). Agribusiness development model for strengthening the chili-tobacco intercropping farmer group. International Journal of Life Sciences, 4(1), 26-36. 
and non-paddy fields such as existing plantations and supported by soil fertility, the availability of water provides opportunities for agribusiness-oriented farming such as chili-tobacco intercropping.

The chili-tobacco intercropping in Bali Province is a unique farming because: (1) the chili and tobacco plants have the same family, namely Solanaceae, but they can grow and develop well together; (2) using seeds with local varieties that are commonly used for generations; (3) tobacco that is developed is shredded tobacco used for betel quid and traditional ceremonies. The development of various chili and smallholder tobacco plants in Bali Province from 2013 to 2016 continues to experience fluctuations ranging from the harvested area, production and productivity, as shown in Table 2 .

Table 2

Harvested area, production, and productivity of various chili and tobacco commodities in Bali province from 2013 to 2016

\begin{tabular}{llllllll}
\hline & & \multicolumn{6}{c}{ Commodity } \\
\cline { 3 - 8 } No & Year & \multicolumn{5}{c}{ Various kinds of chili } & \multicolumn{3}{c}{ Smallholder tobacco plants } \\
\cline { 3 - 8 } & & $\begin{array}{l}\text { Harvested } \\
\text { Area (Ha) }\end{array}$ & $\begin{array}{l}\text { Production } \\
\text { (Ton) }\end{array}$ & $\begin{array}{l}\text { Productivity } \\
\text { (Ton/Ha) }\end{array}$ & $\begin{array}{l}\text { Harvested } \\
\text { Area (Ha) }\end{array}$ & $\begin{array}{l}\text { Production } \\
\text { (Ton) }\end{array}$ & $\begin{array}{l}\text { Productivity } \\
\text { (Ton/Ha) }\end{array}$ \\
\hline 1 & 2013 & 4.044 & 35.856 & 8.86 & 434 & 406,56 & 0.93 \\
2 & 2014 & 5.243 & 48.788 & 9.30 & 332 & 302,18 & 0.91 \\
3 & 2015 & 5.085 & 45.386 & 8.92 & 238 & 251,28 & 1.05 \\
4 & 2016 & 5.114 & 51.325 & 10.03 & 378 & 320,01 & 0.84 \\
\hline \multicolumn{2}{l}{ Average } & 4.871 & 45.338 & 9.27 & 345 & 320,00 & 0.93 \\
\hline
\end{tabular}

Source: Central Bureau of Statistics, 2017

Based on factual data, the development of production of various chili and smallholder tobacco plants nationally did not meet the targets of the Ministry of Agriculture and experienced fluctuations in harvested area, production and productivity caused by several things such as the management of the upstream, middle and downstream agribusiness systems that were poorly integrated. To overcome the above, it is necessary to find solutions and innovations by utilizing the potential of existing areas, one of which is through the farming of chili-tobacco intercropping by developing an agribusiness system.

Based on the explanation above, it is necessary to develop an agribusiness system development model that is suitable for strengthening the chili-tobacco intercropping farmer group. This model illustrates and simplifies the real phenomena of the chili-tobacco intercropping agribusiness system by highlighting the most important elements and ignoring the non-essential elements so that they can be used as a working reference (Paryono \& Sutikno, 2003; Jatmiko, 2007; Bambang, 2014; Yusuf et al., 2016).

\section{Materials and Methods}

\section{Research design}

This study uses a survey research design to investigate the problems that occur in the field and study the dependent variables which are the main problems to further find the cause.

\section{Research sites}

This research was conducted at the location of the chili-tobacco intercropping farm in the Province of Bali. This location was chosen deliberately (purposive) with consideration, namely: (1) Bali Province has the potential for the development of a chili-tobacco intercropping; (2) chili-tobacco intercropping is a unique farm, because plants that have the same family can grow well together; (3) most still use local variety seeds; (4) tobacco developed is chopped tobacco used for betel quid and traditional ceremonies; (5) chili-tobacco commodities are national and regional superior commodities; (6) chili-tobacco commodities often cause inflation for a country or region. 
Population

The population of this research is all farmers who have implemented the chili-tobacco intercropping farming in 2016 and 2017 in the Province of Bali. The total population is 1,482 farmers, spread in two districts and three districts, namely (1) Gianyar Regency consists of (a) Sukawati District, consisting of Sukawati Village, Batubulan Kangin Village, Celuk Village and Guwang Village; (b) Payangan Sub-district covers Kerta Village and Buahan Kaja Village; (2) Bangli Regency consists of (a) Kintamani Sub-District covering Langgahan Village. In detail, the population and sample of the study are outlined in Table 3.

\section{Research sample}

Determination of respondent or sample of population is done by using the formulation of Slovin theory (Sujarweni, 2014), which is formulated as follows:

$$
\begin{aligned}
\mathrm{n} & =\frac{\mathrm{N}}{1+\left(\mathrm{N} \mathrm{x} \mathrm{e}^{2}\right)}=\frac{1.482}{1+\left(1.482 \times 0,05^{2}\right)}=\frac{1.482}{4,705}=314,9 \text { (rounded up 315) } \\
\mathrm{n} & =\text { Sample size } \\
\mathrm{N} & =\text { Population } \\
\mathrm{e} & =\text { the percentage of looseness is due to desirable sampling errors. }
\end{aligned}
$$

Based on the above calculation, the overall number of samples in this study was 315 respondents. In detail, the population and sample of the study are outlined in Table 3.

Table 3

Total data distribution of farmer groups, population, and research samples

\begin{tabular}{lllllll}
\hline & & & & \multicolumn{2}{c}{ Total } \\
\cline { 5 - 6 } No & Regency & sub-district & Village name & $\begin{array}{l}\text { Farmer } \\
\text { Group }\end{array}$ & $\begin{array}{l}\text { Population } \\
\text { (person) }\end{array}$ & $\begin{array}{l}\text { samples } \\
\text { (person) }\end{array}$ \\
\hline 1 & Gianyar & Sukawati & Sukawati & 13 & 756 & 160 \\
2 & Gianyar & Sukawati & Batubulan Kangin & 4 & 454 & 96 \\
3 & Gianyar & Sukawati & Celuk & 1 & 112 & 24 \\
4 & Gianyar & Sukawati & Guwang & 2 & 40 & 9 \\
5 & Gianyar & Payangan & Kerta & 2 & 50 & 11 \\
6 & Gianyar & Payangan & Buahan Kaja & 1 & 40 & 9 \\
7 & Bangli & Kintamani & Langgahan & 1 & 30 & 6 \\
\hline & Total & & & 24 & 1.482 & 315 \\
\hline
\end{tabular}

Source: Gianyar Regency Agriculture Office and Bangli Regency Agriculture, Food Security and Fisheries Service.

Data analysis methods using statistical inference with PLS

Quantitative data from the results of this study were analyzed by statistical inference methods using Component-Based SEM (Structural Equation Modeling) analysis with Smart PLS (Partial Least Square) version 2.0 M3 software. Measurement of the level of importance and certainty of the need for field activities are analyzed using the Strategic Assumption Surfacing and Testing (SAST) method.

Adnyana, I. N. S., Darmawan, D. P., Windia, I. W., \& Suamba, I. K. (2020). Agribusiness development model for strengthening the chili-tobacco intercropping farmer group. International Journal of Life Sciences, 4(1), 26-36. 


\section{Results and Discussions}

3.1 The influence of the procurement and distribution subsystems of production facilities for strengthening the chili-tobacco intercropping farmer groups

The procurement and distribution subsystems of production facilities have a positive effect on strengthening the Chili-Tobacco inter-cropping Farmers Group as shown in Table 2. The path parameter coefficient value obtained from the influence of the procurement and distribution subsystems of production facilities (X1) for strengthening the Chili-Tobacco inter-cropping Farmers Group (Y) is 0.650 with a t-test value of 39.715> 1.967 (t-table) at a significance level of 5\%; this shows that the hypothesis of the procurement and distribution subsystems of production facilities has a positive and real effect for the strengthening of the ChiliTobacco inter-cropping Farmers Group in Bali Province can be proven.

\subsection{The influence of farming subsystems for strengthening the chili-tobacco intercropping farmer groups}

The farming subsystem has a positive effect on the strengthening of the Chili-Tobacco inter-cropping Farmer Group shown in Table 4. The path parameter coefficient value obtained from the relationship of farming subsystem (X2) for strengthening the Chili-Tobacco inter-cropping Farmer Group existing in Bali Province (Y) is 0.080 with the $\mathrm{t}$-count value of $2.889>1.967$ ( $\mathrm{t}$-table) at a significance level of $5 \%$; this shows that the farming subsystem hypothesis has a positive and real effect on strengthening the Chili-Tobacco inter-cropping Farmer Group in Bali Province can be proven.

Table 4

Structural model path coefficients analysis results

\begin{tabular}{llll}
\hline Relationship between variables & $\begin{array}{l}\text { Parameter } \\
\text { coefficient }\end{array}$ & Standard error & t-statistics \\
\hline $\begin{array}{l}\text { The subsystem of procurement and distribution of } \\
\text { production facilities to strengthen intercropping } \\
\text { farmer groups }\end{array}$ & 0,650 & 0,016 & 39,715 \\
$\begin{array}{l}\text { Farm subsystem for strengthening intercropping } \\
\text { farmer groups }\end{array}$ & 0,080 & 0,027 & 2,889 \\
$\begin{array}{l}\text { Post-harvest subsystem and advanced processing to } \\
\text { strengthen intercropping farmer groups }\end{array}$ & 0,091 & 0,031 & 2,853 \\
$\begin{array}{l}\text { Crop marketing subsystem to strengthen } \\
\text { intercropping farmer groups }\end{array}$ & 0,097 & 0,042 & 2,278 \\
$\begin{array}{l}\text { Support services subsystem for strengthening } \\
\text { intercropping farmer groups }\end{array}$ & 0,116 & 0,033 & 3,470 \\
\end{tabular}

3.3 The effects of post-harvest subsystems and further processing for the strengthening of chili-tobacco intercropping farmer groups

Post-harvest subsystems and advanced processing have a positive effect on strengthening the Chili-Tobacco intercropping farmer groups shown in Table 4. The path parameter coefficient value obtained from the relationship between the post-harvest subsystem and advanced processing (X3) for strengthening the ChilliTobacco intercropping farmer groups in the Province of Bali (Y) is 0.091 with a calculated value of 2.853> 1.967 (t-table) at the level of significance of 5\%; this shows that the hypothesis of the post-harvest subsystem and advanced processing has a positive and real effect on the strengthening of the Chili-Tobacco intercropping groups in the Province of Bali can be proven. 


\subsection{The effect of yield marketing subsystems on strengthening the chili-tobacco intercropping farmer groups}

The yield marketing subsystem has a positive effect on strengthening the Chili-Tobacco intercropping farmer groups shown in Table 4. The path parameter coefficient value obtained from the relationship of the yield marketing subsystem (X4) for strengthening the Chilli-Tobacco (Y) intercropping farmer group (Y) is 0.097 with a calculated value of 2.278> 1.967 (t-table) at a significance level of 5\%; this shows that the marketing subsystem hypothesis has a positive and real effect on strengthening the Chili-Tobacco farmer groups in the Province of Bali can be proven.

3.5 The effect of the supporting services subsystem for strengthening the chili-tobacco intercropping farmer groups

The support services subsystem has a positive effect on strengthening the Chilli-Tobacco intercropping farmer groups shown in Table 2. The path parameter coefficient value obtained from the relationship of supporting services subsystem (X5) to strengthen the Chilli-Tobacco (Y) intercropping farmer group (Y) is 0.116 with a ttest value of 3.470>1.967 (t-table) at a significance level of 5\%; this shows that the hypothesis of a support services subsystem has a positive and real effect for the strengthening of the Chili-Tobacco intercropping group in the Province of Bali can be proven.

By looking at the effect of exogenous constructs on endogenous constructs shown in Figure 1, it can be seen how much direct influence between exogenous constructs is on endogenous constructs. The direct effect of the procurement and distribution subsystems of production facilities is 0.650 , the direct influence of the

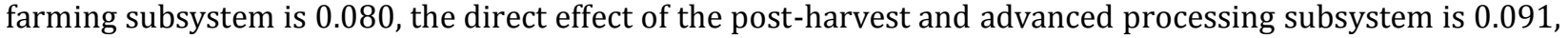
the direct effect of the marketing subsystem is 0.097 , the direct effect of supporting services was 0.116 for strengthening the Chili-Tobacco intercropping farmer groups. Of the five factors, the procurement and distribution subsystems of production facilities have the most direct relative influence of 0.650 for strengthening the Chili-Tobacco intercropping farmer groups in the Province of Bali.

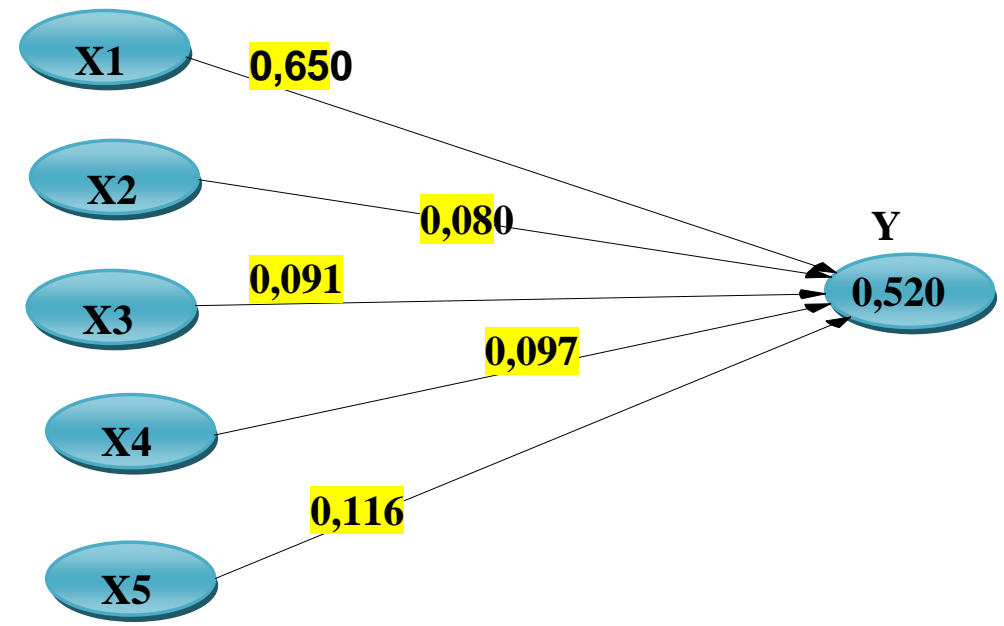

Figure 1. Structural model of the effect of exogenous constructions on endogenous constructions

3.6 Development Model of the Agribusiness System that is suitable for Strengthening the Chili-Tobacco intercropping Farmer Group

Agribusiness is a business activity that is engaged in agriculture that has been oriented to profit, agribusiness people consistently strive to obtain commercial and financial value on an ongoing basis to produce products that the market needs (Adjid, 1998; Antara, 2006; Muliarta, 2016; and Hermawan, 2008). Agribusiness consists of five subsystems, namely the enterprise subsystem and the procurement and distribution of

Adnyana, I. N. S., Darmawan, D. P., Windia, I. W., \& Suamba, I. K. (2020). Agribusiness development model for strengthening the chili-tobacco intercropping farmer group. International Journal of Life Sciences, 4(1), 26-36. https://doi.org/10.29332/ijls.v4n1.387 
agricultural production facilities, farming subsystems, product processing subsystems (agroindustry), yield marketing subsystems and supporting services subsystems (Suparta, 2005).

The problems experienced so far are farming subsystems, marketing subsystems, production, and income, which are still classified as low categories. One of the efforts that have been made by the government in making an increase in Human Resources for farmers of the chili-tobacco intercropping is through the application of field schools, which have proven to be more effective in increasing farmers 'knowledge, skills, and attitudes towards farmers and can increase farmers' production and income (Rejesus et al., 2012; Phillips et al., 2014; Victor et al., 2017). Field schools will also open up the creativity of farmers in terms of knowledge, practice, and the use and preservation of natural enemies (Palis, 2006; Guoa et al., 2015; Lampe, 2016).

The development of the field school then needs to apply the pattern of the agribusiness system, which is to accommodate the application of the five subsystems so that it synergizes with what is the goal. The material aspects given should refer to the development of the agribusiness system such as (1) conducting a field school on the availability of agricultural production facilities; (2) implementing the Integrated Pest Control Field School; (3) implementing the Field School of Good Agricultural Practices (GAP); (4) implementing the Field School of Good Handling Practices (GHP); (5) implementing the Field School of Good Manufacturing Practices (GMP) (6) implementing the Field School of Marketing and (7) implementing the Field School of Support Services.

Material aspects of supporting service development need to also be taken seriously (1) access to capital; (2) who is doing the daily assistance in the field; (3) what is the role of agricultural cooperatives; (4) what is the state of transportation in the agricultural region; (5) what is the condition of primary, secondary and tertiary irrigation in the agricultural area. The agribusiness system development model that is suitable for strengthening the chili-tobacco intercropping farmer group can be seen in Figure 2.

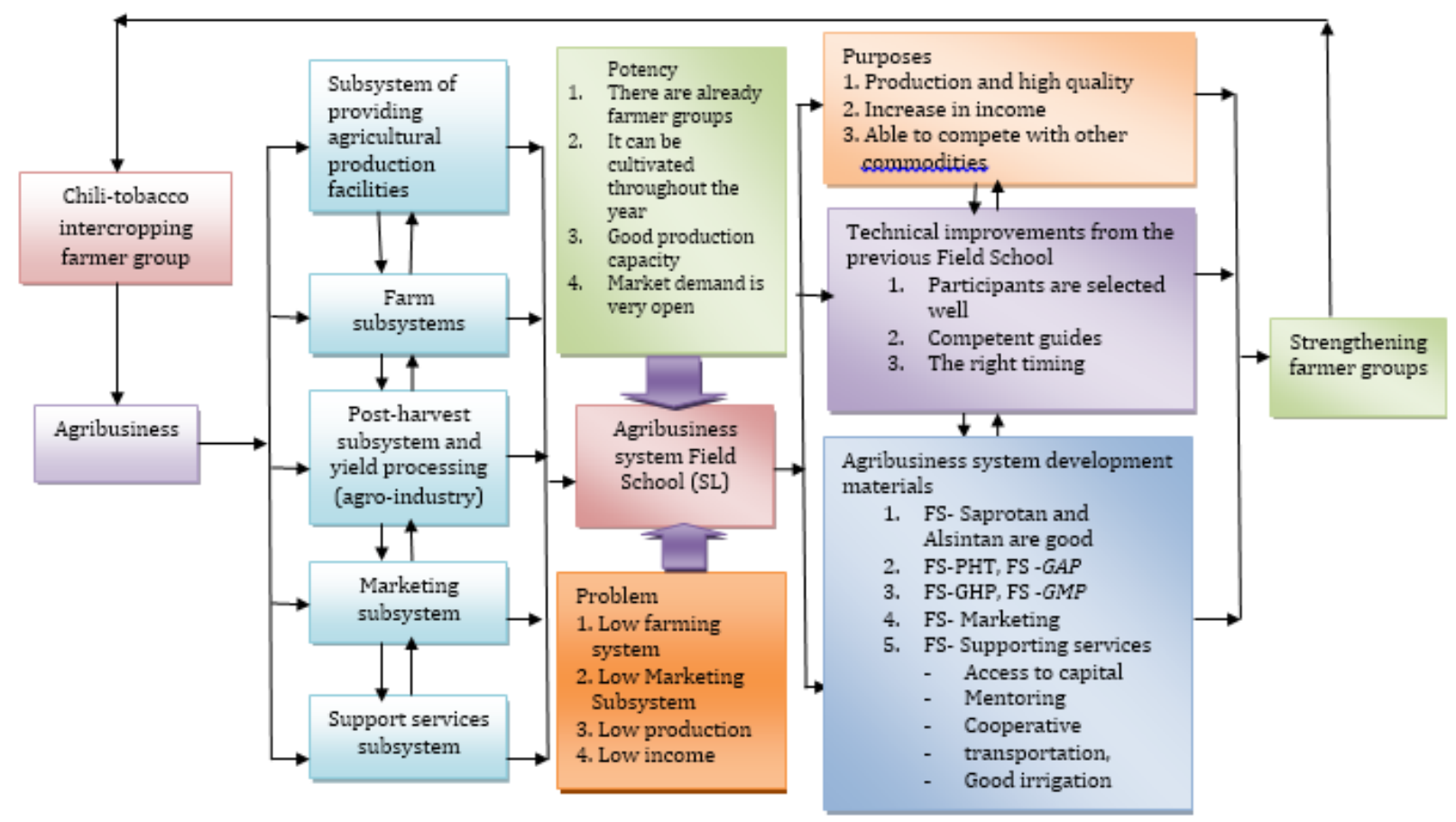

Figure 2. Agribusiness system development model that is suitable for strengthening farmer-tobacco intercropping farmer groups

The results of the analysis of the Strategic Assumptions Surfacing and Testing (SAST) that have been carried out on the experts obtained the results of the need for seven strategic field school activities to solve problems and then group them into assumptions or quadrants. The results of grouping all activity assumptions are in the first quadrant that is certain and important as directed in Figure 3.3. The seven strategic activities are sorted according to the level of needs of the Chili-Tobacco Intercropping Farmer Group in the field, namely (1) 
Field School of Marketing (4.7: 4.9); (2) Field School of Good Agriculture Practices (GAP) $(4,5: 4,6)$; $(3)$ Integrated Pest Control Field School (SL-PHT) (4,3: 4,4); (4) Field School of Good Handling Practices (GHP) (4.0: 4.2); (5) Field School of Good Manufacturing Practices (GMP) (3.8: 4.0); (6) Field School of Supporting Services (3.6: 3.7); and (7) Field School for Provision of Agricultural Production Facilities (3.5: 3,6).

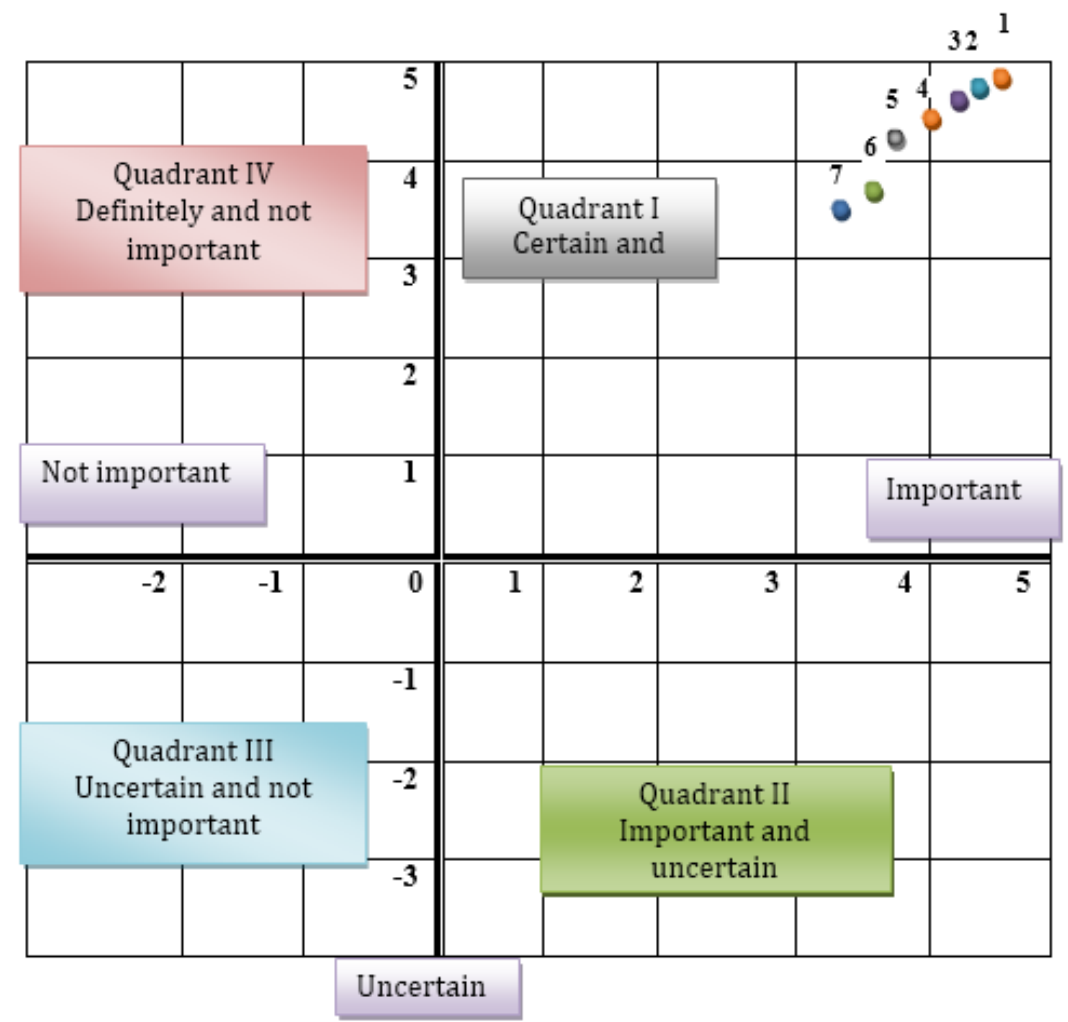

Figure 3. The need for agribusiness system field schools using the SAST method for strengthening chili-tobacco intercropping farmer group

\section{Conclusion}

Based on the results of the analysis and discussion, it can be concluded as follows.

a) The procurement and distribution subsystems of production facilities have a positive and tangible effect on strengthening the Chili-Tobacco Farmer Group in Bali Province.

b) The farming subsystem has a positive and real effect on the strengthening of the Chili-Tobacco Intercropping Farmers Group in Bali Province.

c) Post-harvest subsystems and advanced processing have a positive and tangible effect on the strengthening of the Chili-Tobacco Intercropping Farmers Group in Bali Province.

d) The results marketing subsystem has a positive and tangible effect on strengthening the Cabai-Tobacco intercropping Farmers Group in Bali Province.

e) Supporting services subsystem has a positive and tangible effect for strengthening the Chili-Tobacco Intercropping Farmer Group in Bali Province.

f) The agribusiness system development model that is suitable for strengthening the Chili-Tobacco intercropping Farmers Group in the Province of Bali can be done through the field of agribusiness system including the field-marketing school, GAP field school, IPM field school, GHP field school, field school GHP, field school -GMP, field school-Supporting services and field school-Provision of

Adnyana, I. N. S., Darmawan, D. P., Windia, I. W., \& Suamba, I. K. (2020). Agribusiness development model for strengthening the chili-tobacco intercropping farmer group. International Journal of Life Sciences, 4(1), 26-36. 
Agricultural Production Facilities. Whereas the Field-Marketing field school is most needed by farmer groups in the field.

\section{Suggestions}

Based on the results of discussions, conclusions and facts in the field related to the results of this research, some suggestions can be given as follows.

1) Marketing subsystems should be improved through the formation of cooperative institutions, utilizing the existence of the Joint Farmers Groups (Gapoktan) or BUMDes to market their chili and tobacco products more professionally.

2) Farming subsystems will be further improved, by improving things that have not been responded to by farmers to run according to operational standards set by the government.

3) Field schools with an agribusiness system need to be re-done include Field Schools-Market, Integrated Field Schools-Pest Control, Field Schools-Good Agriculture Practices (SL-GAP), Field Schools-Good Handling Practices (SL-GHP), Field Schools- Good Manufacturing Practices (GMP), Field School-Support Services and SL-Provision of Agricultural Production Facilities.

4) Other studies with different models and variables need to be done so that better R-Square value can be obtained.

Acknowledgments

We are grateful to two anonymous reviewers for their valuable comments on the earlier version of this paper. 


\section{References}

Adjid, D. A. (1998). Bunga rampai agribisnis: kebangkitan, kemandirian, dan keberdayaan masyarakat pedesaan menuju abad 21. Surat Kabar Sinar Tani.

Antara, M. (2006). Manajemen Agribisnis (Bahan Ajar). Program Magister Agribisnis, Universitas Udayana. Denpasar.

Badan Pusat Statistik Provinsi Bali. (2017). Bali Dalam Angka 2017. Denpasar.

Bambang, A. S. (2014). Perbedaan model dan teori dalam ilmu komunikasi. Humaniora, 5(2), 1153-1160. https://doi.org/10.21512/humaniora.v5i2.3255

Guo, M., Jia, X., Huang, J., Kumar, K. B., \& Burger, N. E. (2015). Farmer field school and farmer knowledge acquisition in rice production: Experimental evaluation in China. Agriculture, Ecosystems \& Environment, 209, 100-107. https://doi.org/10.1016/j.agee.2015.02.011

Hermawan, R., \& SP, M. (2008). Membangun Sistem Agribisnis. Agroinfo. Yogyakarta.

Jatmiko, R.H. 2007. Filsafat Geografi, Sekolah Pasca Sarjana, Universitas Gajah Mada. Yogyakarta

Lampe, M. (2016). 'Sekolah Lapang Petani': Membangun Komitmen, Disiplin dan Kretivitas Petani Melalui SLPPHT. ETNOSIA: Jurnal Etnografi Indonesia, 1(1).

Muliarta, I. N. (2016). The evaluation of implementation of integrated farming system program and the reality of increasing farmers income in Bali. International Research Journal of Engineering, IT \& Scientific Research, 2(7), 108-114.

Palis, F. G. (2006). The role of culture in farmer learning and technology adoption: a case study of farmer field schools among rice farmers in central Luzon, Philippines. Agriculture and Human Values, 23(4), 491-500. https://doi.org/10.1007/s10460-006-9012-6

Paryono, P., \& Sutikno, P. P. D. H. (2003). Pemodelan citra digital perubahan lingkungan biogeofisik wila yah pesisir menggunakan citra landsat thematic mapper. Suatu telaah analitik dan fisik lingkungan atas kegiatan pertambangan di Kabupaten Mimika Papua. Universitas Gadjah Mada Yogyakarta, Yogyakarta.

Phillips, D., Waddington, H., \& White, H. (2014). Better targeting of farmers as a channel for poverty reduction: A systematic review of farmer field schools targeting. Development Studies Research. An Open Access Journal, 1(1), 113-136. https://doi.org/10.1080/21665095.2014.924841

Rejesus, R. M., Mutuc, M. E. M., Yasar, M., Lapitan, A. V., Palis, F. G., \& Chi, T. T. N. (2012). Sending Vietnamese rice farmers back to school: Further evidence on the impacts of farmer field schools. Canadian Journal of Agricultural Economics/Revue canadienne d'agroeconomie, 60(3), 407-426. https://doi.org/10.1111/j.1744-7976.2011.01242.x

Saragih, B. (2003). Pembangunan sistem agribisnis di indonesia dan Peranan public relation. SOCA: Jurnal Sosial Ekonomi Pertanian.

Sujarweni, V. W. (2014). Metode Penelitian: Lengkap, Praktis, dan Mudah Dipahami.

Suparta, N. (2005). Pendekatan Holistik Membangun Agribisnis. CV Bali Media Adhikarsa. Denpasar.

Victor, A. N., Luqman, M., Shiwei, X., Wen, Y., \& Majeed, M. Z. (2017). Farmer field school's training on knowledge level of citrus growers regarding improved production practices. Ciência Rural, 47(10). http://dx.doi.org/10.1590/0103-8478cr20160784

Yusuf, M., Adiputra, N., Sutjana, I. D. P., \& Tirtayasa, K. (2016). The improvement of work posture using rapid upper limb assessment: analysis to decrease subjective disorders of strawberry farmers in Bali. International Research Journal of Engineering, IT \& Scientific Research, 2(9), 1-8.

Adnyana, I. N. S., Darmawan, D. P., Windia, I. W., \& Suamba, I. K. (2020). Agribusiness development model for strengthening the chili-tobacco intercropping farmer group. International Journal of Life Sciences, 4(1), 26-36. 


\section{Biography of Authors}

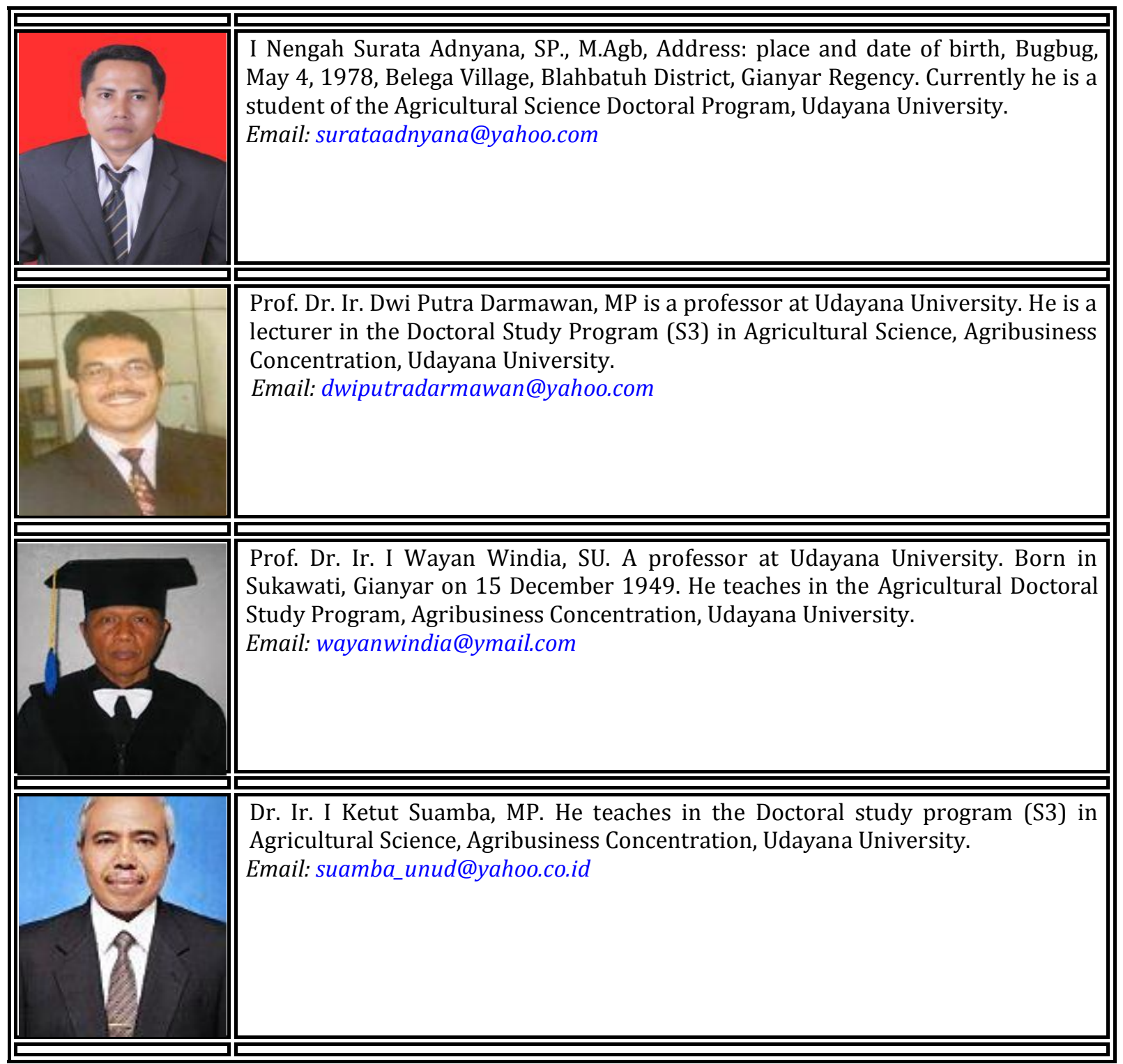

